\title{
Survey of physicians concerning the use of chest radiography in the diagnosis of pneumonia in out-patients
}

\author{
THOMAS J MARRIE MD FRCPC
}

\begin{abstract}
TJ MARRIE. Survey of physicians concerning the use of chest radiography in the diagnosis of pneumonia in out-patients. Can J Infect Dis 1997;8(2):95-98.

OBJECTIVE: To determine how physicians use chest radiography in the diagnosis of pneumonia in ambulatory patients. STUDY POPULATION: A convenience sample of 176 Nova Scotia family physicians and internists selected to represent all geographic areas of the province proportional to population.

STUDY INSTRUMENT: A 35-item questionnaire covering demographics, experience with out-patients with pneumonia, use of chest radiographs to make this diagnosis and factors that were considered important in the decision to perform initial and follow-up chest radiographs. Two skill-testing questions were also included.

RESULTS: One hundred and fourteen of $176(64.7 \%)$ responded; $88 \%$ had treated out-patients with pneumonia in the previous three months. Fifty-seven per cent of physicians requested chest radiographs on $90 \%$ to $100 \%$ of out-patients in whom they had made a clinical diagnosis of pneumonia. These physicians were more likely to be internists and to have graduated before 1970. Factors that ranked most important in the decision to request the initial chest radiograph were clinical appearance, respiratory distress and physical findings, while age and smoking history contributed most to the decision to perform a follow-up chest radiograph.

CONCLUSIONS: There is considerable variability among physicians in requesting chest radiographs on out-patients with a clinical diagnosis of pneumonia. Physician and patient factors contribute to this variability.
\end{abstract}

Key Words: Chest radiographs, Out-patients, Pneumonia

Sondage auprès des médecins au sujet de la radiographie pulmonaire dans le diagnostic de la pneumonie chez les patients non hospitalisés

OBJECTIF : Déterminer comment les médecins utilisent la radiographie pulmonaire pour le diagnostic de la pneumonie chez les patients non hospitalisés.

POPULATION ÉTUDIÉE : Échantillon de commodité de 176 médecins de famille et internistes néo-écossais choisis pour représenter toutes les régions géographiques de la province, en proportion de la population.

INSTRUMENT DU SONDAGE : Un questionnaire en 35 points couvrant les données démographiques, l'expérience auprès de patients ambulatoires atteints de pneumonie, le recours à la radiographie pulmonaire pour poser le diagnostic et les facteurs jugés importants dans la décision d'effectuer des radiographies initiales et de suivi. Deux questions de vérification des connaissances ont également été incluses.

voir page suivante

Departments of Medicine and Microbiology, Dalhousie University and Victoria General Hospital, Halifax, Nova Scotia Correspondence and reprints: DR TM Marrie, Victorial General Hospital, Room 5014 ACC, 1278 Tower Road, Halifax, Nova Scotia B3H 2 Y9. Telephone 902-428-5553, fax 902-428-7094, e-mail tmarrie@is.dal.ca

Received for publication February 23, 1996. Accepted July 30, 1996 
RÉSULTATS : Cent-quatorze médecins sur $176(64,7 \%)$ ont répondu. Quatre-vingt-huit pour cent avaient traité des patients non hospitalisés souffrant de pneumonie au cours des trois mois précédants. Cinquante-sept pour cent des médecins ont demandé des radiographies pulmonaires pour 90 à $100 \%$ des patients non hospitalisés chez qui ils avaient posé un diagnostic de pneumonie sur des bases cliniques. Ces médecins étaient davantage des internistes et avaient terminé leurs études avant 1970. Les facteurs jugés les plus importants pour demander une radiographie pulmonaire initiale étaient : le tableau clinique, la détresse respiratoire et les signes physiques. Alors que l'âge et les antécédents de tabagisme ont contribué davantage à la décision de procéder à des radiographies pulmonaires de suivi.

CONCLUSIONS : On note une variabilité considérable entre les médecins qui demandent des radiographies pulmonaires pour leurs patients non hospitalisés chez qui un diagnostic clinique de pneumonie est posé. Les facteurs propres aux médecins et aux patients contribuent à cette variabilité.

$\mathrm{P}$ neumonia is a common illness affecting 10 to 12 adults per 1000 per year (1). Up to $80 \%$ of cases of pneumonia are treated at home (2). However, most of our knowledge about pneumonia is derived from studies of patients with pneumonia who are admitted to hospital (3-7). Indeed we have no information about the diagnosis of pneumonia in those who are treated as out-patients, such as how many receive a chest radiograph. This is a central question because at the moment it is considered to be the gold standard for pneumonia diagnosis. The objectives of this study were to determine how physicians used chest radiographs in the diagnosis of out-patient pneumonia and to determine the factors that physicians consider when deciding to order a chest radiograph.

\section{STUDY DESIGN}

A convenience sample of physicians was selected from the Nova Scotia registry. Only internists and family doctors were selected, and physicians throughout the province were sampled proportional to the population.

A 35-item questionnaire was mailed to 176 physicians. The questionnaire inquired about physician demographics; experience with out-patients with pneumonia; and decision making regarding the ordering chest radiographs for these patients (a series of characteristics were presented and the physician was asked to rank the importance of each factor from 1 to 5 with 5 being most important). In addition two skill-testing questions were included.

TABLE 1

Number of 114 physicians who ordered initial and follow-up chest radiographs on out-patients with a clinical diagnosis of pneumonia

\begin{tabular}{lcc}
\hline $\begin{array}{l}\text { Percentage of } \\
\text { patients given } \\
\text { a chest } \\
\text { radiograph }\end{array}$ & $\begin{array}{c}\text { Number of } \\
\text { physicians (\%) who } \\
\text { ordered initial } \\
\text { chest radiographs }\end{array}$ & $\begin{array}{c}\text { Number of } \\
\text { physicians (\%) who } \\
\text { ordered follow-up } \\
\text { chest radiographs }\end{array}$ \\
\hline 10 or less & $21(18.4)$ & $23(20)$ \\
11 to 30 & $8(7)$ & $9(8)$ \\
31 to 50 & $6(5.3)$ & $21(18)$ \\
51 to 70 & $11(9.6)$ & $4(4)$ \\
71 to 80 & $10(8.8)$ & $12(11)$ \\
81 to 90 & $3(2.6)$ & $5(4)$ \\
91 to 100 & $55(48.2)$ & $40(35)$ \\
\hline
\end{tabular}

\section{RESULTS}

One hundred and fourteen of the 176 (64.7\%) physicians from 19 areas throughout Nova Scotia responded. Most respondents, $73 \%$, were family physicians, $25 \%$ were internists and $2 \%$ were emergency room physicians. Forty (35\%) had graduated since 1980, 51 during 1970 s (44.7\%) and the remainder before this.

One hundred and two (89\%) had treated patients with pneumonia as out-patients in the previous three months. Twenty-five per cent of physicians treated seven or more patients with pneumonia during this time period. Fifty-seven (49\%) ordered chest radiographs on $91 \%$ to $100 \%$ of patients in whom they made a clinical diagnosis of pneumonia (Table 1). Twenty-two of the $29(76 \%)$ internists stated they ordered chest radiographs on $91 \%$ to $100 \%$ of patients in whom they suspected pneumonia compared with 33 of 83 (40\%) family physicians $(\mathrm{P}<0.001)$. Time since graduation seemed to be an influence because 19 of 40 (47.5\%) graduates from 1980 to present; 26 of 51 (51\%) graduates from 1970 to 1979; and 19 of $25(76 \%)$ of those who graduated before 1970 ordered chest radiographs on $91 \%$ to $100 \%$ of patients with pneumonia. The factors that physicians considered in ordering chest radiographs are presented in Table 2. Clinical appearance, respiratory distress and physical findings were the most important factors in this decision.

Forty per cent of physicians indicated that they ordered follow-up chest radiographs in $91 \%$ to $100 \%$ while $23 \%$ ordered these radiographs in only $0 \%$ to $10 \%$ of patients (Table 1 ). Indeed in this side-by-side comparison there was little difference in the proportions of physicians who ordered initial and follow-up chest radiographs. Thirty physicians (26.3\%) said they ordered initial and follow-up chest radiographs on $100 \%$ of patient suspected of having pneumonia. The factors that they considered important in the decision to do a follow-up chest radiograph are given in Table 3 . All 102 physicians who replied to a question about how often they had seen a patient with carcinoma of the lung who initially presentated with pneumonia had seen such a patient at least once.

The answers to the skill-testing questions are presented in Tables 4 and 5.

\section{DISCUSSION}

This study shows that almost half the physicians who participated in this study obtained a chest radiograph in nearly all their patients in whom they made a clinical diagnosis of pneumonia and that $18 \%$ almost never obtained chest 
TABLE 2

Factors that physicians $(n=114)$ considered important in their decision to perform a chest radiograph on a patient with pneumonia

\begin{tabular}{lc}
\hline Factor & Rating* \\
\hline Clinical appearance & $4.5 \pm 1$ \\
Respiratory distress & $4.5 \pm 0.9$ \\
Physical findings & $4.4 \pm 1$ \\
Low PO $_{2}$ & $4.26 \pm 2.3$ \\
Abnormal vital signs & $4.18 \pm 1.15$ \\
Altered mental status & $4.14 \pm 1.6$ \\
Failure to respond to initial antibiotic & $4.07 \pm 1.3$ \\
$\quad$ therapy & \\
High white blood cell count & $3.649 \pm 1.8$ \\
Presence of chronic obstructive lung & $3.57 \pm 1.17$ \\
$\quad$ disease & \\
Temperature & $3.5 \pm 1.46$ \\
Patient's age & $3.5 \pm 1.2$ \\
Smoking history & $3.41 \pm 1.3$ \\
Patient wanted a chest radiograph & $2.48 \pm 1.35$ \\
\hline *Each item was rated on a scale of 1 to 5 with 1 being least and 5 being \\
most important; rating mean \pm SD
\end{tabular}

TABLE 3

Factors that physicians $(n=114)$ considered important in their decision whether to perform a follow-up radiograph on an out-patient whom they had treated for pneumonia

\begin{tabular}{lc}
\hline Factor & Rating* \\
\hline Age 65 years or greater & $4.07 \pm 1.2$ \\
Smoking history & $3.58 \pm 1.3$ \\
Presence of chronic obstructive lung & $3.56 \pm 1.26$ \\
$\quad$ disease & \\
Satisfactory response to therapy & $3.50 \pm 1.5$ \\
Patient reliability & $3.0 \pm 1.3$ \\
Patient does not want a chest radiograph & $2.9 \pm 1.3$ \\
Cost to health care system & $2.8 \pm 1.2$ \\
Patient inconvenience & $2.6 \pm 1.2$ \\
Risk of radiation exposure & $1.89 \pm 1.22$ \\
\hline
\end{tabular}

*Each item was rated on a scale of 1 to 5 with 1 being least and 5 being most important, rating mean $\pm S D$

radiographs. However, internists were more likely to obtain chest radiographs on almost all their patients compared with family doctors. In Nova Scotia internists act as consultants; thus, it is likely that the patients with pneumonia that they see on referral from family physicians are different from those treated without referral. Those who graduated before 1970 were more likely to obtain radiographs on most of their patients compared with those who graduated later.

The top five factors cited in the decision to perform a chest radiograph are all indicative of severity of the pneumonia and make clinical sense. Age greater than 65 years and smoking history were the most common reasons for doing a follow-up chest radiograph.

Unfortunately our study indicates only what physicians

\section{TABLE 4}

Response to skill-testing question 1 from survey Question: A 60-year-old male, an 80-pack-a-year smoker with chronic obstructive lung disease, has a right upper lobe pneumonia due to Streptococcus pneumoniae. He responds promptly to treatment with penicillin. In your estimation when will his pneumonia have resolved radiographically?

\begin{tabular}{lc}
\hline $\begin{array}{l}\text { Time to resolution } \\
\text { (weeks) }\end{array}$ & $\begin{array}{c}\text { Number of } \mathbf{1 1 0} \text { physicians }(\%) \\
\text { giving an answer }\end{array}$ \\
\hline 2 & $10(9.09)$ \\
3 & $24(21.82)$ \\
4 & $29(26.36)$ \\
5 & $7(6.36)$ \\
6 & $29(26.36)$ \\
7 & $1(0.91)$ \\
8 & $8(7.27)$ \\
9 & $0(0)$ \\
10 & $2(1.82)$ \\
\hline
\end{tabular}

TABLE 5

Response to skill-testing question 2 from survey Question: A 22-year-old female nonsmoker with right upper lobe pneumonia responds promptly to your treatment. In your estimate when will her pneumonia have resolved radiographically?

\begin{tabular}{lc}
\hline $\begin{array}{l}\text { Time to resolution } \\
\text { (weeks) }\end{array}$ & $\begin{array}{c}\text { Number of } \mathbf{1 1 2} \text { physicians }(\%) \\
\text { giving an answer }\end{array}$ \\
\hline 2 & $38(33.93)$ \\
3 & $29(25.89)$ \\
4 & $27(24.11)$ \\
5 & $4(3.57)$ \\
6 & $10(8.93)$ \\
7 & $0(0)$ \\
8 & $4(3.57)$ \\
\hline
\end{tabular}

say they do and not what they really do. It is evident that clinicians over- and underdiagnose pneumonia clinically. Melbye et al (9) evaluated the diagnostic value of typical symptoms and abnormal chest signs against a radiographic reference in a study of 402 patients. Twenty patients had radiographic evidence of pneumonia. Physicians made a clinical diagnosis of pneumonia in seven (35\%) of these patients and in 22 others with normal chest radiographs. However, one must remember that the chest radiograph may not be the most sensitive method of diagnosing pneumonia. At the moment it is the best we have; although, ${ }^{111}$ In-labelled granulocytes (12) or high resolution computed tomography may be better, they are clearly impractical for screening purposes. Studies of patients with Pneumocystis carinii pneumonia (PCP) indicate that for this diagnosis the chest radiograph may be a tarnished gold standard in that $39 \%$ of patients with PCP had a normal chest radiograph (10).

Diehr et al (11) tried to predict pneumonia in out-patients with acute cough. They found that 48 of $1819(2.6 \%)$ had 
radiographic evidence of pneumonia. They noted that 32 findings were significant predictors of pneumonia. From this study, they developed a diagnostic rule that identified pneumonia patients with $91 \%$ sensitivity and $40 \%$ specificity. Fever, night sweats, chills, smoking history, sputum production, pulse rate greater than 100 beats/min, respiratory rate greater than 25 breaths/min, temperature $37.7^{\circ} \mathrm{C}$ or greater, dullness to percussion, rales, pleural rub and aegophony increased fremitus were all predictors.

Woodhead et al (8) found that pneumonia accounted for $5.6 \%$ (224 of 4027 ) of all lower respiratory tract infections for which antibiotics were prescribed.

Jay et al (13) studied 72 patients with bacteremic pneumococcal pneumonia and found that consolidation disappeared in all patients by eight to 10 weeks. Age greater than 50 years, chronic obstructive pulmonary disease and alcoholism were associated with delayed resolution. These findings indicate that $90 \%$ of the physicians who answered the question in Table

\section{REFERENCES}

1. Foy HM, Cooney MK, Allan I, et al. Rates of pneumonia during influenza epidemics in Seattle, 1964 to 1975. JAMA 1979;241:253-8

2. Foy HM, Wentworth B, Kenny GE, et al. Pneumococcal isolations from patients with pneumonia and control subjects in a prepaid medical care group. Am Rev Respir Dis 1977;111:595-603.

3. Fang G-D, Fine M, Orloff J, et al. New and emerging etiologies for community-acquired pneumonia with implications for therapy. A prospective multicenter study of 359 cases. Medicine 1990;69:307-16.

4. Marrie TJ, Durant H, Yates L. Community-acquired pneumonia requiring hospitalization: 5 year prospective study. Rev Infect Dis 1989;11:586-99.

5. Fekety FR Jr, Caldwell J, Gump D, et al. Bacterial viruses and mycoplasmas on acute pneumonia in adults. Am Rev Respir Dis 1971;104:499-507.

6. Sullivan RJ Jr, Dawdle WR, Marrie WM, et al. Adult pneumonia in a general hospital etiology and host risk factors. Arch Intern Med 1972;129:935-42.

7. Dorff GJ, Rytel MW, Farmer SG, et al. Etiologies and characteristic features of pneumonia in a municipal hospital. Am J Med Sci 1973;266:349-58.
4 underestimated the time for the 62-year-old male smoker with chronic obstructive lung disease to clear his pneumonia. Mittl and co-workers (14) studied 37 in-patients and 44 outpatients with pneumonia. The mean time to clear pneumonia in out-patients was 3.8 weeks versus 9.1 weeks for in-patients. Nonsmokers cleared the pneumonia in five weeks and smokers in 8.4 weeks.

Sixteen per cent of physicians overestimated the time for the 22-year-old female to clear her pneumonia in our study (Table 5).

It is evident from our observations that both patient and physician factors contribute to the decision of who receives a chest radiograph for the diagnosis of out-patient pneumonia.

ACKNOWLEDGEMENTS: This research was supported by a grant from the Nova Scotia Lung Foundation.

8. Woodhead MA, Macfarlane JT, McCraken JS, Rose DH, Finch RG. Prospective study of the aetiology and outcome of pneumonia in the community. Lancet 1987;i:671-4.

9. Melbye H, Straume B, Aasebo U, Dali K. Diagnosis of pneumonia in adults in general practice. Scand J Prim Health Care 1992;10:226-33.

10. Opravil M, Mavinecek B, Fuchs WA, et al. Shortcomings of chest radiography in detecting Pneumocystis carinii pneumonia. J Acquired Immun Defic Syndr 1994;7:39-45.

11. Diehr P, Wood RW, Bushyhead J, Krueger L, Wolcott B, Tompkins RK. Prediction of pneumonia in out-patients with acute cough A statistical approach. J Chronic Dis 1984;37:215-25.

12. Lichter JP, Ronald G, Konopka G, Hartman MT, Moser KM, Spragg G. The in vivo behaviour of granulocytes labelled with indium-111 in a canine model of pneumococcal pneumonia. Am Rev Respir Dis 1984;129:602-6.

13. Jay SJ, Johanson WP Jr, Pierce AK. The radiographic resolution of Streptococcus pneumoniae pneumonia. N Engl J Med 1975;293:798-801.

14. Mittl RL Jr, Schwab RJ, Duchin JS, et al. Radiographic resolution of community-acquired pneumonia. Am J Respir Crit Care Med 1994;149:630-5. 


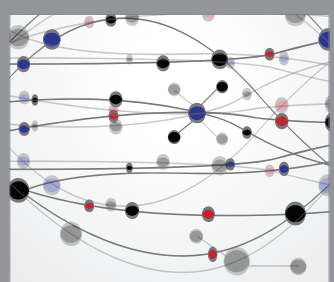

The Scientific World Journal
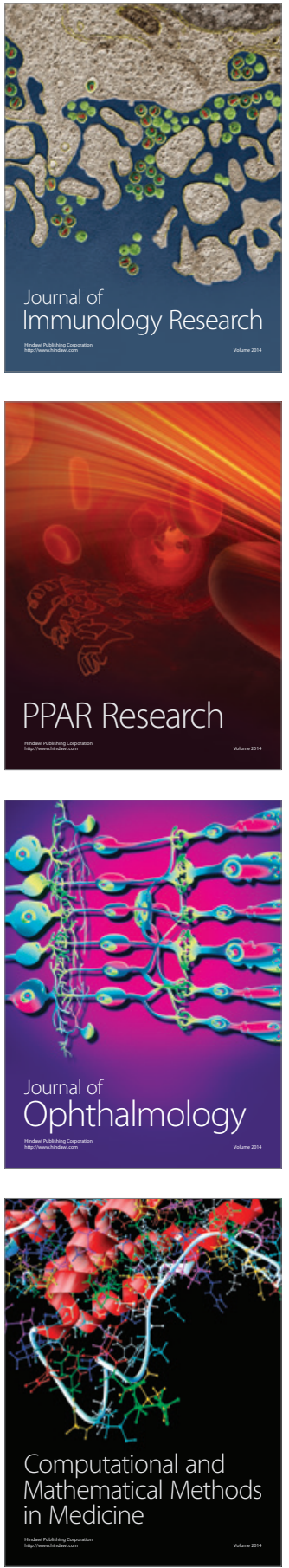

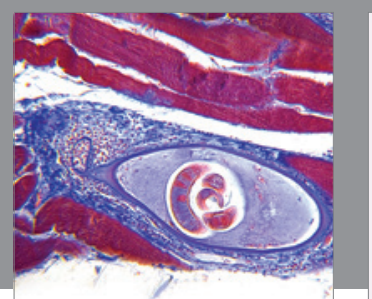

Gastroenterology Research and Practice

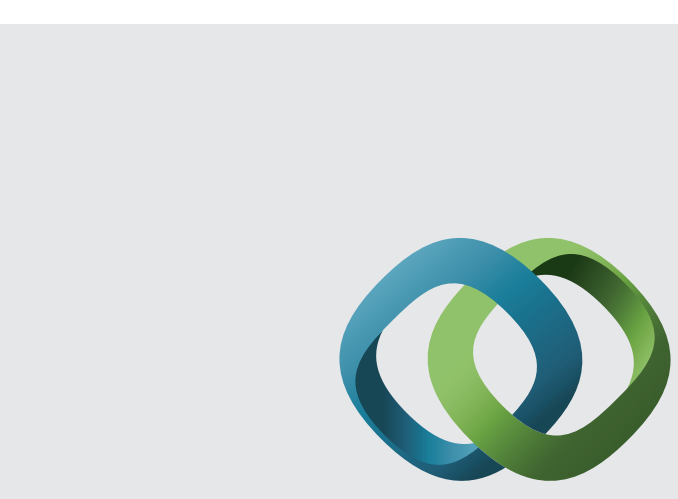

\section{Hindawi}

Submit your manuscripts at

http://www.hindawi.com
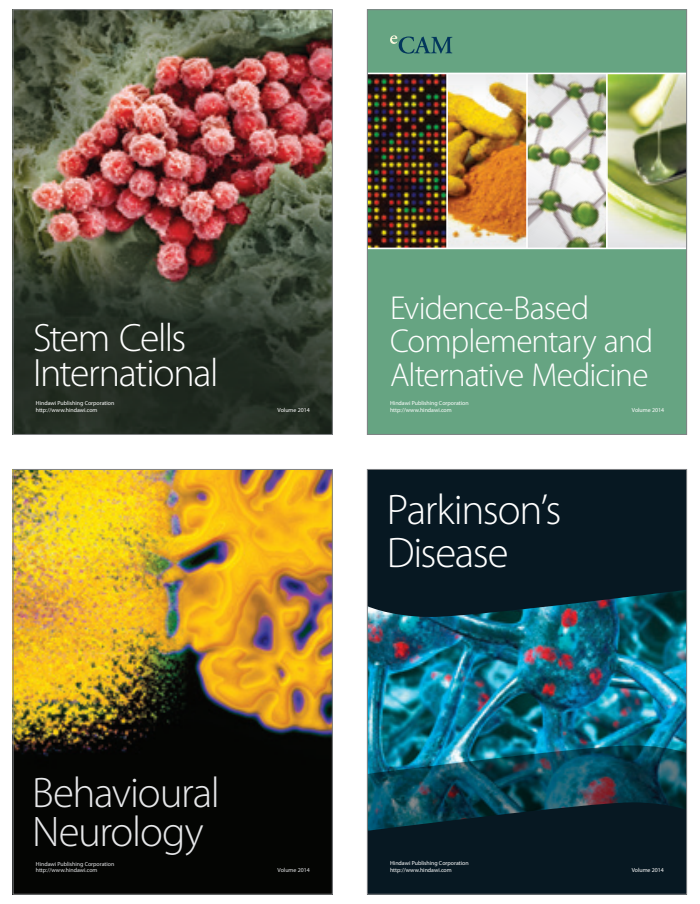
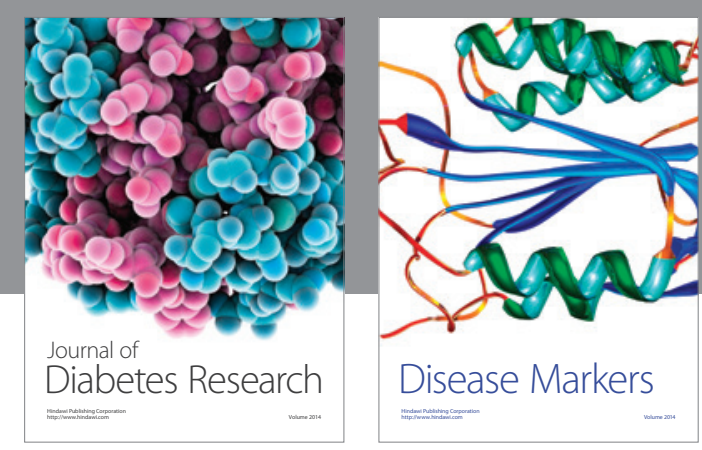

Disease Markers
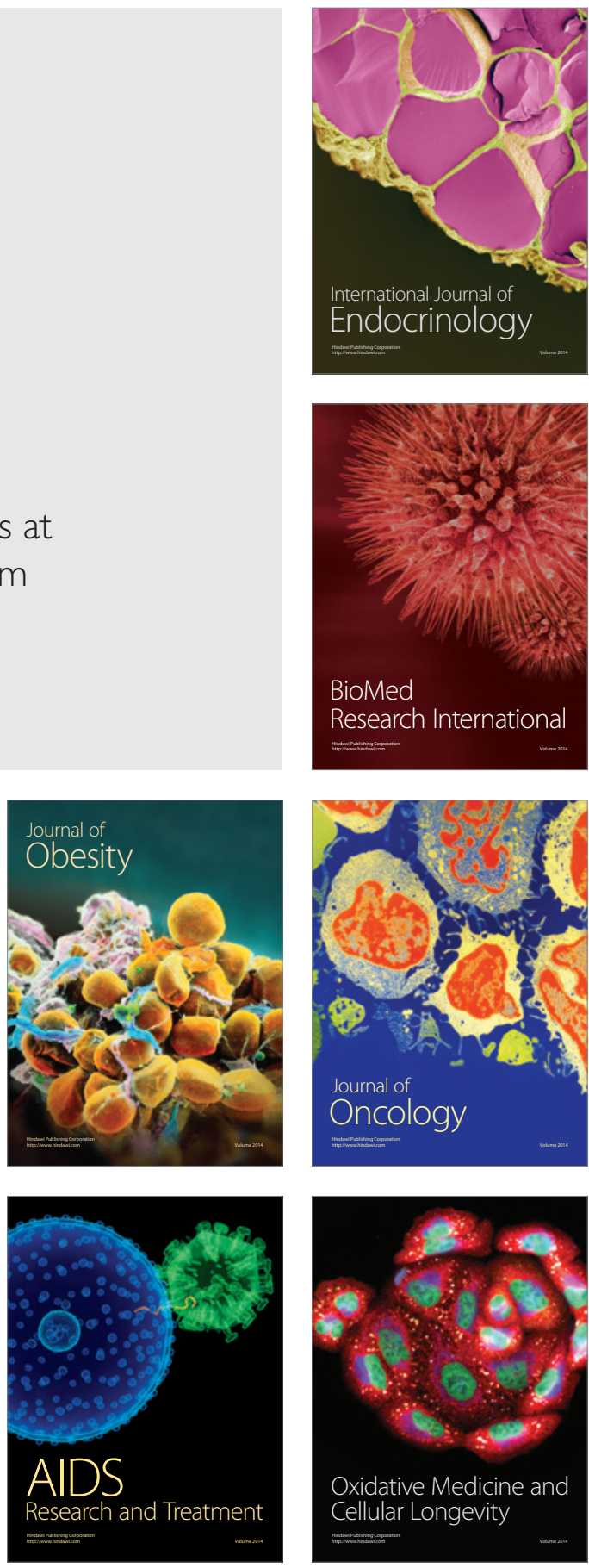